\title{
声門下癌の臨床的検討
}

\author{
北海道大学医学部耳喵喉科学教室（主任：犬山征夫教授）

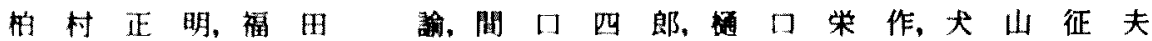

\section{CLINICAL STUDY OF SUBGLOTTIC CARCINOMA}

\author{
MASAAKI KASHIWAMURA, M.D., SATOSHI FUKUDA, M.D., SHIROH MAGUCHI, M.D. \\ EISAKU HIGUCHI, M.D. and YUKIO INUYAMA, M.D. \\ Department of Otolaryngology. Hokkaido University School of Medicine, Sapporo
}

Recently, therapy for laryngeal carcinoma has been becoming established, particularly in the early stage. The prognosis of laryngeal carcinoma is said to be better than that of other head and neck carcinomas. Laryngeal carcinoma is divided into 3 subtypes, supraglottic, glottic and subglottic, according to origin. We analyzed the subglottic carcinomas diagnosed and treated in our department between 1972 and 1990. During that period we treated 515 cases of laryngeal carcinoma, 204 cases of the supraglottic type. 284 cases of the glottic type, and 27 cases $(5.2 \%)$ of the subglottic type. The 5-year survival rate in subglottic carcinoma was $44 \%$ (T1:83\%, T2 : $55 \%, \mathrm{~T} 3: 17 \%, \mathrm{~T} 4: 0 \%$ ), worse than in the other types of laryngeal carcinoma.

We think that there were 2 main reasons for the worse prognosis. The first was their high rate of local recurrence after radiation therapy particularly in the early stage. Although $15 \mathrm{~T} 1$ and T2 patients who received full dose $(65 G y)$ radiotherapy had a complete response, 8 patients developed local recurrence. The results of the salvage operation were good in $\mathrm{Tl}$ cases, but were followed by death because of metastasis or second recurrence in 2 of the $3 \mathrm{~T} 2$ patients. The second reason for the worse prognosis appeared to be metastasis in the advanced cases. Five (50\%) T3 and T4 patients developed metastasis to the lung, mediastinum and cervical lymph nodes, resulting in death.

Thus, we believe that the main therapy for subglottic carcinoma, except $\mathrm{T} 1$, should be surgery to obtain a better outcome, and that adjuvant chemotherapy after irradiation or neck (paratracheal) dissection with total laryngectomy should be performed in advanced cases.

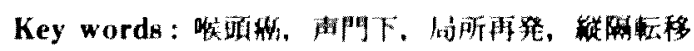

A $98-0254-60309$

はしめに

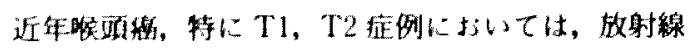

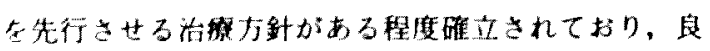

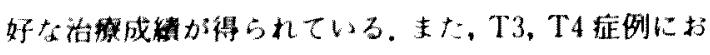

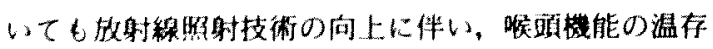

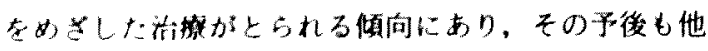

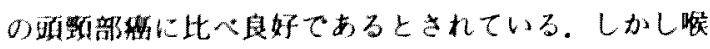

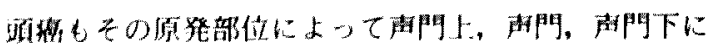

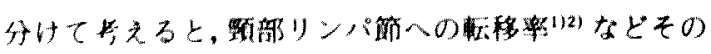

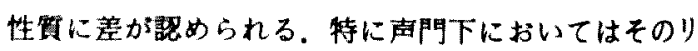

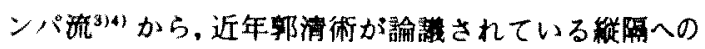
転移も多いと考えられ，予後の孯さが予想される。

今回われわれは，当科に扔いて治潦した声門下嗝症

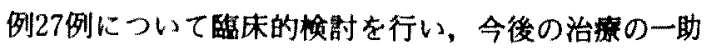
と成り得る知見を得たため文献的検时を加えて報告す 3 . 
就

\section{1. 对层}

対象は1972年から1990年末てO19年間に当科にて治

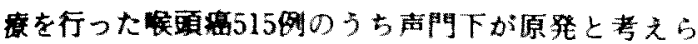

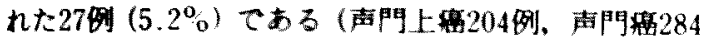

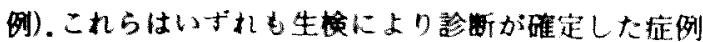

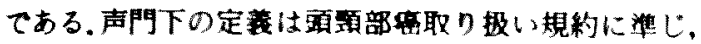

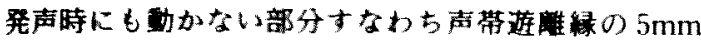

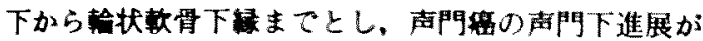
䢃わんた症例は除外した。

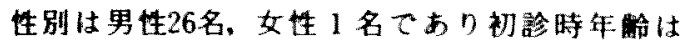

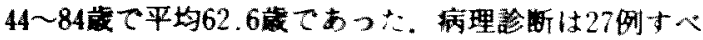
$\tau$ squamous cell carcinoma $\tau \delta っ t$.

2. 察期間

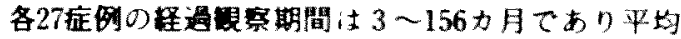
55.0力月てちった。

3. TNM

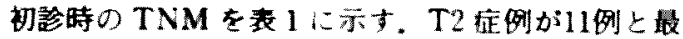

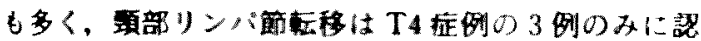
ゆんた。

4. 主嗮

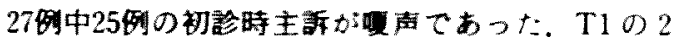

衰 1 TXM

\begin{tabular}{|c|c|cc|c|c|}
\hline & $N 0$ & $N 1$ & $N 2$ & $N 3$ & 新 \\
\hline $\mathrm{T} 1$ & 6 & 0 & 0 & 0 & 6 \\
\hline $\mathrm{T} 2$ & 11 & 0 & 0 & 0 & 11 \\
\hline $\mathrm{T} 3$ & 6 & 0 & 0 & 0 & 6 \\
\hline $\mathrm{T} 4$ & 1 & 2 & 1 & 0 & 4 \\
\hline
\end{tabular}

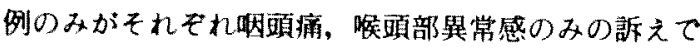
あった。また重禎主訴として祭下時痛をT3，T4に1 例ずつ敫めた。

\section{治方等}

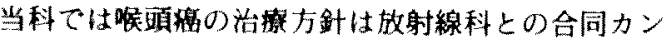
ファレンスにて各拉例ごとに检討している，放射線治

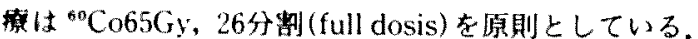
T1、T2䘑例については原则的に 65Gy まて照射する

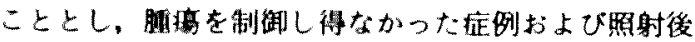
の同峢に刘しては salvage operation（主として喉䫄

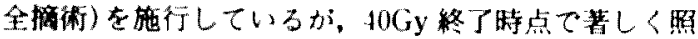

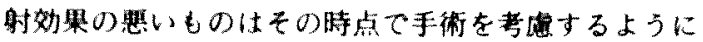
している．T3，T4 䞄例に対しては 40Gy 特点での照射

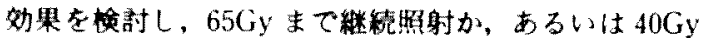
を林前照射として手術（主に㬋影全摘術）を施行する 次定している。

$65 \mathrm{~Gy}$ 照射を施行した症例で照射䅂了後腫軳の残

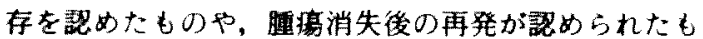

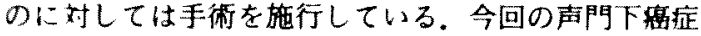
例に对する治撩も上述の方法に準じた，その内容を表 2 に示与。27例中26例が初回治原を放射線掠法とした がT3の1例は腄癁が声門下の半周以上に進展してい

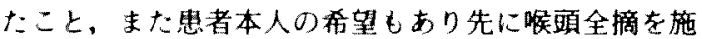
行した，放射線整独治撩を行った症例が15例と多かっ

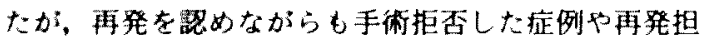

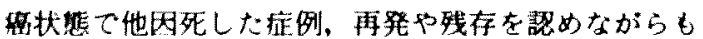

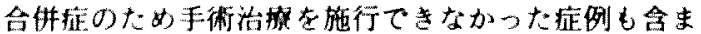

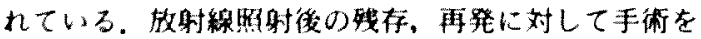

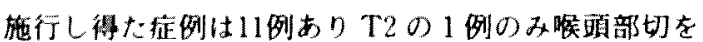

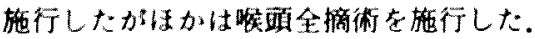

哀 2 治腆

\begin{tabular}{|c|c|c|c|c|c|c|}
\hline & $\mathrm{T} 1$ & $\mathrm{~T} 2$ & T3 & \multicolumn{3}{|c|}{$\mathrm{T} 4$} \\
\hline & 全响 No & 全例 No & 全例 No & No & $\mathrm{N} 1$ & N2 \\
\hline 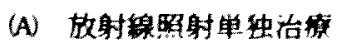 & $3(1)$ & $6(2)$ & $4(3)$ & 0 & $1(1)$ & $1(1)$ \\
\hline 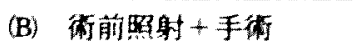 & & & & & & \\
\hline 1. $40 \mathrm{~Gy}$ - 手林 & $1(0)$ & $1(0)$ & $1(1)$ & $1(1)$ & $1(1)$ & 0 \\
\hline $\begin{array}{l}\text { 2. } \quad 65 \mathrm{~Gy} \div \text { 手得 } \\
\text { (radiation failure) }\end{array}$ & 0 & $1(0)$ & 0 & 0 & 0 & 0 \\
\hline 3. $65 \mathrm{~Gy}$ 後再軓手侕 & $2(0)$ & $3^{\bullet}(2)$ & 0 & 0 & 0 & 0 \\
\hline (C) その地 & 0 & 0 & $1($ f 术 $)(1)$ & & 0 & \\
\hline
\end{tabular}

* 1 例のみ hemilaryngectomy, 他は total laryngectomy 


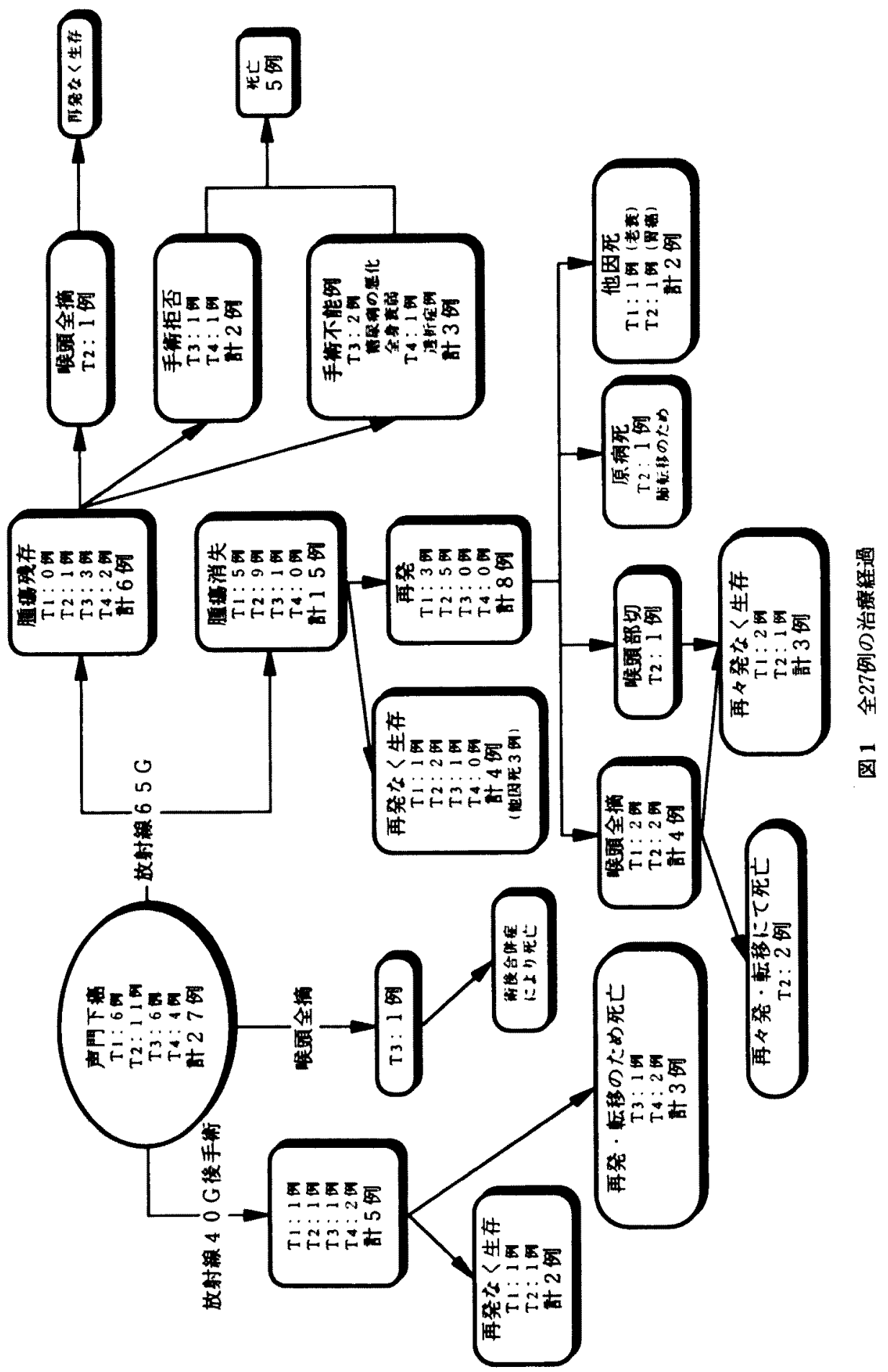


衰 3 予後

\begin{tabular}{|c|c|c|c|}
\hline & 生存 & 原病死 & 他因死 \\
\hline $\mathrm{T} 1$ (6 例) & 4 & 1 & 1 \\
\hline $\mathrm{T} 2$ (11例) & 5 & 4 & 2 \\
\hline $\mathrm{T} 3(6$ 例) & 1 & 5 & 0 \\
\hline $\mathrm{T} 4$ (4 例) & 0 & 4 & 0 \\
\hline 計 & 10 & 11 & 3 \\
\hline
\end{tabular}

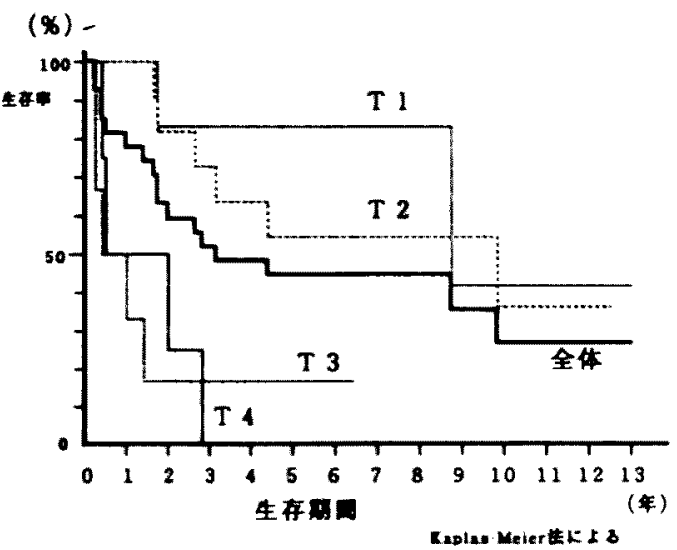

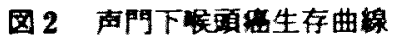

放射臬の照射野については，原則的にT1は诶頭，

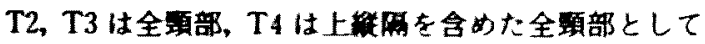
いたが、放射湶科医によって若干の差曽が訆められた。

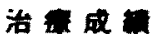

\section{1. 予後}

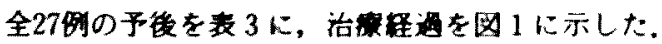
Kaplan-Meier 法老用いた 5 年生存平（因2）は全体て 44\%と以前当科にて娭討した声門禹，声門上禹のそれ より低い值であった2、、ことにみると，T1は83\%て あり声門盘とほほ同等ておったが，T2が55\%と低く， T3，T4に图してはそれそれ17\%，0\%であり，10列中 8 例が原病死という要い结果であった。

\section{2. 再発}

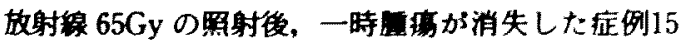
例(T1：5例, T2：9似，T3：1例)のうち，8例(53.5 \%)に局所再無を詪めた（T1：3 例， $\mathrm{T} 2 ： 5$ 例). 照 射終了後加再無まての期間は，T1て $3 ， 93 ， 96$ 力， $\mathrm{T} 2 て 11,13,22,23,30$ 力月であり平均 36.4 力月てあ つた。また手術施行後の再発として，T3症例にて
$40 \mathrm{~Gy}$ 照射十喉頭全摘後10力月で永久気管口周囲の再 発 (stomal recurrence)を認めたものが 1 例あっだ。

照射後再発症例に対する salvage operationの成綪 は, T1ては 3 例の再発例のうち 2 例に喉頭全摘を施 行し、2例と6再々発を認めず生存中でるる。1例は 再発時に92歳と高䟖であったため追加治撚はせず，老 衰にて死亡した。一方，T2 で 5 例の再発例のちち 3 例に手術を施行し得たか，そのうち1例のみ生存して いるが，2例は肺転移のため死亡した。 Stomal recur. rence の应例に対しては，膘清切除，気管切除を施行し たが桔局再々発のため死亡した。

\section{3. 正移}

27例の释過中，移の陻められた症例の出現部位， 丁は以下の通りてあった（们は初影から移出現ま ての期間である。

頚部： T2 2 例 (23力月, 46 力月)

T4 4 例 (12力月, 他 3 例柆初影時)

肺：T2 2 例 (15力月, 23力月)

链 : T3 1 例 (12力月)

T4 1 例 (36力月)

T3，T4症例については10例中 5 例に転移が出現し 非常に高率てあると考元られた。今回の検即で，転 移を现めたもので救命し得た应例はなかった。

1. 発生确度, 蟫床症状について

今回の我々の模郡で、声門下䗎は喉頭禹515例中 27

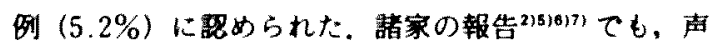
門原発で門門下に主に進展した应例をどう解粎するか

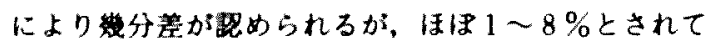

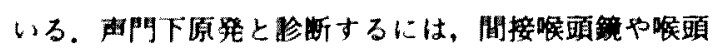
ファイバースコビーによる暏断が传先されるが, 今回

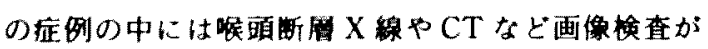

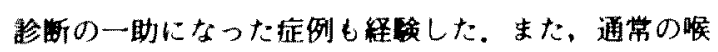

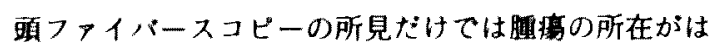

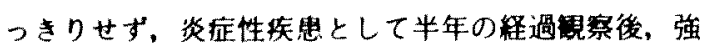
度の頚浮腫を来し気管切開を施行し，気管口からの ファイバースコピーによる睍察で初めて跈断のついた 症例もあり，声門下禹に対する認識の重要性も感じさ せられた。症状については，ほとんどの症例て腹声を 培えていた。 T1 症例ては病変が声带にかからないた め噮声のないしのが 2 例あったが，他の4例てはやは り业声が主新でり，4例とも披裂部，仮声帯の粘膜

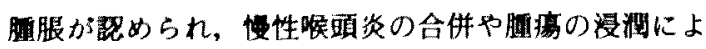


る局所话謤不全に伴う浮腫が原因と考えられた。

2. 治瘖・予後について

今回の梌郡ては，原病死した症例が $\mathrm{T} 1, \mathrm{~T} 2$ 症例て は17例中 5 挒のみでったのに対し T3、T4 症例では 10例中 9 例に認められ，両群の予後には大きな差があ るものと考えられた。しかし，T1，T2 症例においても 放射線単独て制御し得た症例は少なく，65Gy 然射後 徆㴬が消失したと考えられた15例のうち半数以上の8 例 $(53.3 \%)$ に局所再発を愎め，再発事の隌さをうか

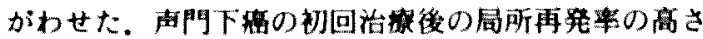
については同様の見解が請家により赧告されてい

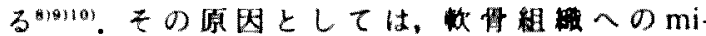

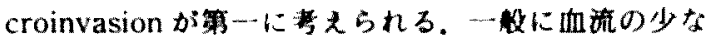

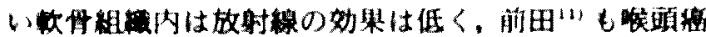

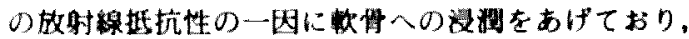

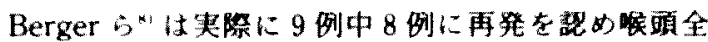

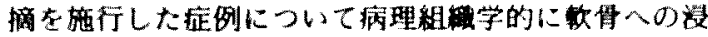
调を㗏明している。また，照射終了から再発まての期 間については，今回の糢討ては 2 年以上の症挒が 3 例 あり上述の再発禹の高さと併世て考えると，放的線治 措に上り肉眼的に腫瘦が消失しても，傎重かつ長期間 にわたる释過锶察が必要と思われた。また再吐の形式 であるか今回の娭郡では初回照射後の局所再無がほと んどであり，術後の stomal recurrenceは1例のみで あった，文献的 ${ }^{101212}$ にはもう少し類度が高いとする報 告が多いが，今回は手術拒否，不能例が多かったため と考える。

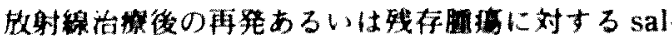
vage operationについては，今回 T3，T4ては部当症 例がなくT1,T2のみての銫封となったが、T1ては全 例が用像制御可能てまったのに对し，T2ては局所再

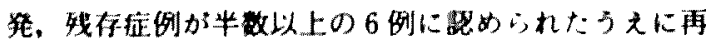
発に対して手術を施行し得た 3 例の弓方 2 例が原病死 して拈り，salvage 低いと思われた。したがって，

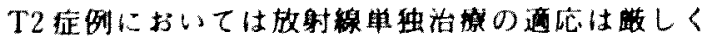
し、最初から手術を念頭においた治撩計画が必要であ ると思われる。また死亡した 2 例に，肺枟移，影部り

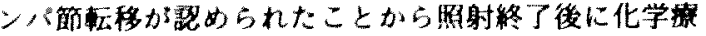
法を併用したり，诶頭全摘時に垔部部清を併施するな

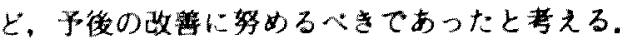

T3，T4拝例については放射線筆独て制御し得た症 例はわずかに1例のみであったことからややはり初め

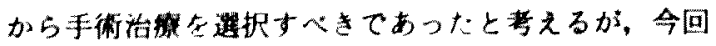
の㛟郡ては T3 症例て照射後の残存，再発に対して手
術を施行し得たものがなく、今後の检討が必要と思わ れる. T4 应例については 4 例すべて死亡しており現 時点ではいすれの治撩を選択しても予後は不良と思わ れな。手術を施行し得た 2 例も䋛隔転移，政部リンパ

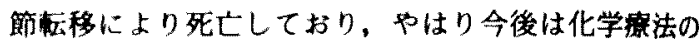

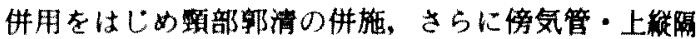

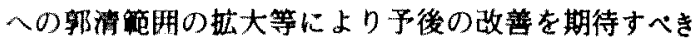
であろう。

今回の検討を行うにあたり，上述の再発率の高さと

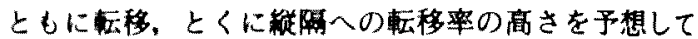
いた．声門下のリンパ流は主として 2 経路あり，1つ は㖮状甲状腺から深㛲部，喉頭前，気管傍のリンパ族 を集める anterior channel，もう一方は输状甲状膜か ら澡到部、鎖每上のリンパ流を集める lateral channel であり、いずれも䋛隔へと注ぐ、したがって頭部同様， 綎成人の自移例は少なくないと予想していたが，実際 にはT3，T4に1例ずつ認めたのみであったしかし 今回の惨討ては15年以上前の古い症例も多数含まれて おり，当時のCT 等の画像の普及状況や耳呕喉科医

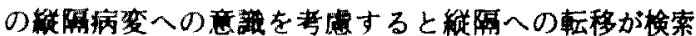
されていなかった可能性が高いと考えられる。実際に， 释過闃祭期間が短くなるため今回の検討から除外した 1991年以降の症例 ${ }^{13)}$ ては，4 例中 2 例に維隔への転移 が訊められており，また声門下滛手術例の50\%に気管

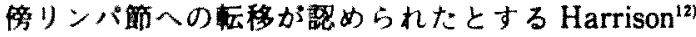
の報告をはじめとして，気管傍リンパ節や綎隔病変を 重要視する報告し見られ(4)，予後の改善のためには同 部位への十分な follow up が必姴と考えられた。碓隔 人の予防照射については放射線科医の間ても推势する

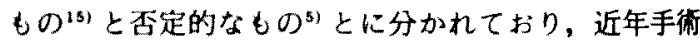
手技の進步に伴い各施設て盛んに施行されつつある維

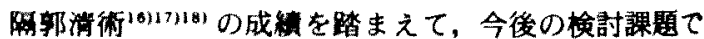
あると思われる。

\section{まとめ}

1.当科に扔ける声門下渴27例について模討した。

2. 全体ての 5 年生存率は $44 \%$ と声門积に比へて德 かった.

3. 初回放射線治缕後の局所再発率が高く，特に T2 症例ては手術による salvage 率も低く，放射線単

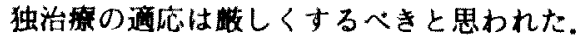

4.予後の改善のためにはあらかじめ手術を念頭に おいた治㧺計画が必要でりり，频部や気管傍リンパ節 の郭清や㫫射終了後の化学撩法の施行も考虑すべきと 
考えられた。

\section{引用文姑}

1) Lederman $M$ : Cancer of the larynx. Part I. Natural history in relation to treatment. $\mathrm{Br} J$ Radiol 44: 569-589, 19 i1.

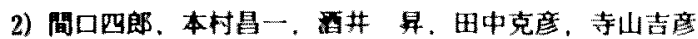

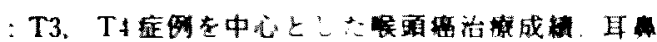
31: 772-7:8, 1985.

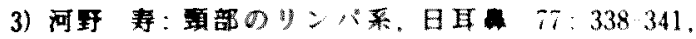
1964 .

4) Welsh LW: The normal human laryngeal lym. phatics Ann Otol Rhinol Laryngol $73: 569 \cdot 582$. 1964.

5) Haylock B]. Deutsch GP: Primary Radiotherapy for Subglottic Carcinoma. Clical Oncol 5: 143 146, 1993.

6) Shaha AR. Shah JP: Carcinoma of the Subglottic Larynx. An J Surger? 144: 456-458, 1982.

7) Vermund $\mathbf{H}$ : Role of radiotherapy in cancer of the larynx as related to the TXM system of staging : A review: Cancer 25: 485-5014, 1970.

8) Berger G, Harwood MB, Bryce DP et al: Primary subglottic carcinoma masquerading clinically as $\mathrm{TI}$ glottic carcinoma. a report of nine cases. J Otolar. yngol 14:1-6, 1985

9) Session DG, Oqura JH. Fried MP et al: Carcinoma of Subglottic Area. Laryngoscope 9: 1417"1423, 1975.

10) Stell PM. Tobin KE: The behavior of cancer affecting the subglottic space. Canad J Otolaryn. gol 4:612-617, 1975 .

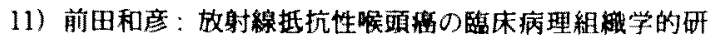
究. 日耳耳 $82: 141-151,1979$.

12) Harrison DFN : The pathology and management of subglottic cancer. Ann Otol Rhinol Laryngol $80: 6$ -12.1971 .

13）拍村正明，㴪田 間四四郎，山田和之，犬山征头

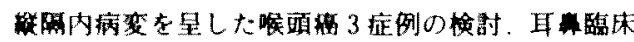

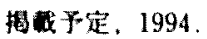

14) Saleh EM, Mancuso AA. Alhussaini AA: Computed tomography of primary subglottic cancer : clinical importance of typical spread pattern. Head and neck .March/April 125" 132, 1992

15) Munro A, Walsh WG: Head and Neck. In Sikora K. Halnan KE (ed). Treatment of cancer. "nd ed. Chapman and Hall, London, 1990, pp 285.

16) Sisson GA, Bytell DE, Becker SP: Mediastinal dissection 1976 ; indications and newer techniques Laryngoscope 87: 751-759, 1976.

17) Sisson GA Sr.: 1989 Ogura memorial lecture mediastianl dissection. Laryngoscope $99: 1262$ 1266,1989

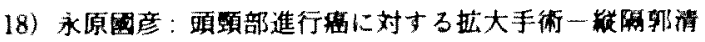
行の問题点一。四 $38: 719 \cdots 727,1992$

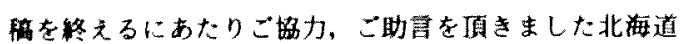

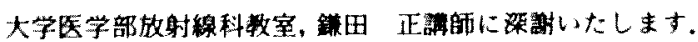

(1994年8月5日受醇 1994年12月1日受理)

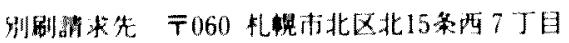

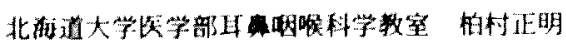




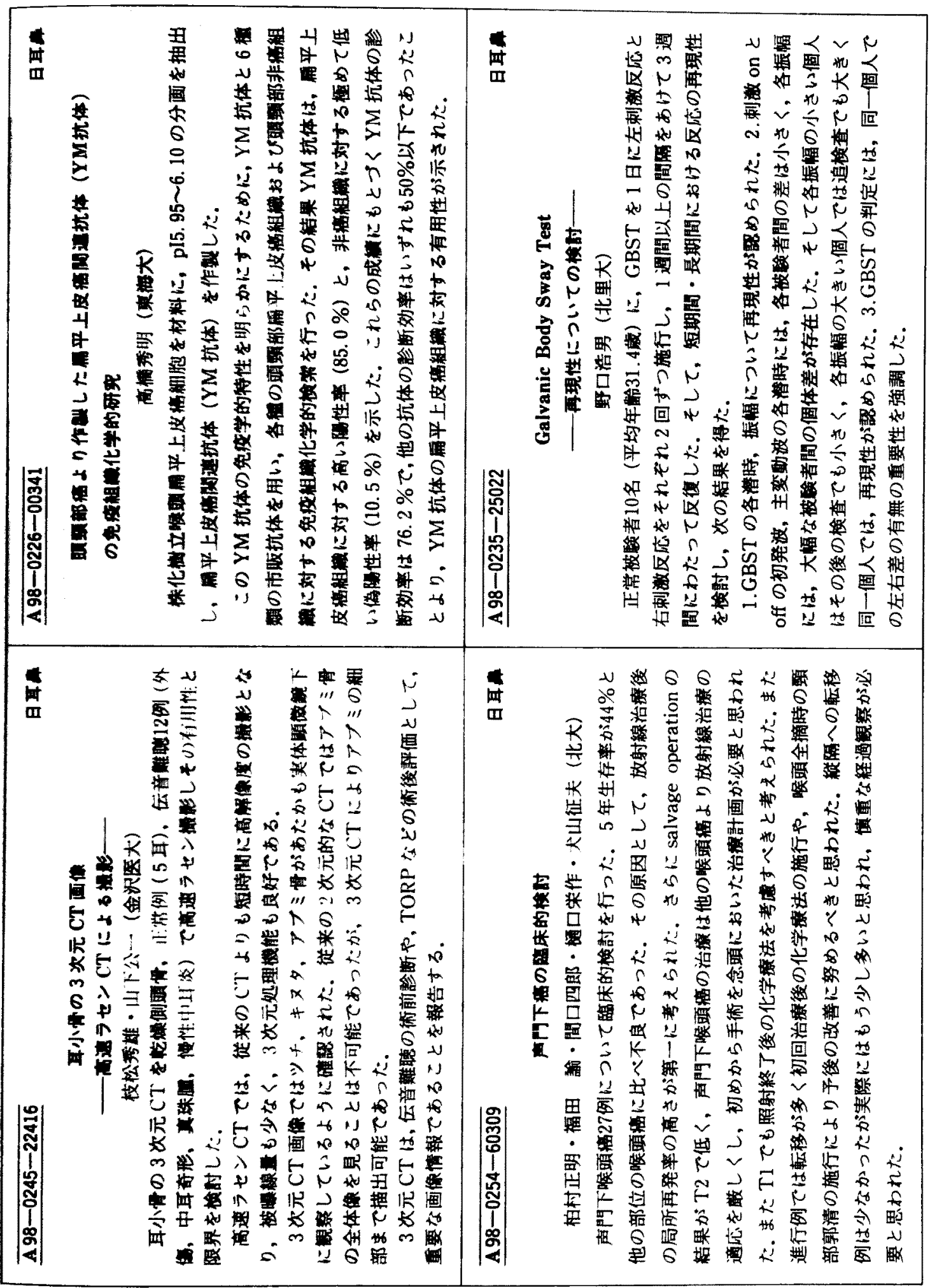

